\title{
Moses Perley and the Fisheries
}

\section{William Welch}

\begin{abstract}
Auteur, naturaliste, homme d'affaires et avocat - ainsi que fonctionnaire - Moses Henry Perley était un personnage familier en Amérique du Nord britannique et au-delà, il y a un siècle et demi. Plus intéressant pour nous aujourd'hui, cependant, sont ses liens avec les pêcheries. En tant qu'observateur et journaliste, Perley a amoncelé des renseignements sur les pêcheries $d u d i x-$ neuvième siècle. Son rôle dans l'histoire de la pêche - en particulier les négociations pour régler les différends avec les États-Unis dans les années 1850 - est l'objet de cet essai.
\end{abstract}

An author, a naturalist, a businessman and a lawyer - as well as a public official - Moses Henry Perley was a familiar figure in British North America and beyond a century and a half ago. Of more interest to us today, however, are his connections with the fisheries. As an observer and reporter, Perley generated a wealth of information on the nineteenth-century fisheries. His role in the history of the fisheries is the subject of the following essay.

Perley was born in New Brunswick in 1804, his family having been part of the great Yankee migration "down-east" that attended the end of the French and Indian wars. Close-knit and prolific, the Perleys were of ancient lineage in their native New England, and, throughout his career, drawn as he was to his heritage and his home, Moses worked diligently, in two societies American and British-American to advance the interests of New Brunswick and the rest of British America. ${ }^{1}$

1 M.V.B. Perley (compiler), History and Genealogy of the Perley Family (Salem, MA: Published by the Compiler, 1906), vi-viii, 1-10, 15-17, 30-33. 52-54, 117-18, 120, 217, 410; W.A. Spray, "Moses Henry Perley" Dictionary of Canadian Biography, (Toronto: University of Toronto Press, 1976), 9: 628-632; "Moses Henry Perley," Dictionary of National Biography (Oxford: Oxford University Press, 1964), 15: 895-896; Philip Cox, "Life of Moses Henry Perley, Writer and Scientist," Proceedings of the Miramichi Natural History Association 4 (1905): 33 40; Moses Perley to Mary Perley, 5, 13, 19 and 24 June 1826 in Moses Perley Letters 1813-1854, typescript, New Brunswick Museum (hereafter NBM), Saint John, NB.

The Northern Mariner/le marin du nord, XXIII No. 1, (January 2013), 21-34 


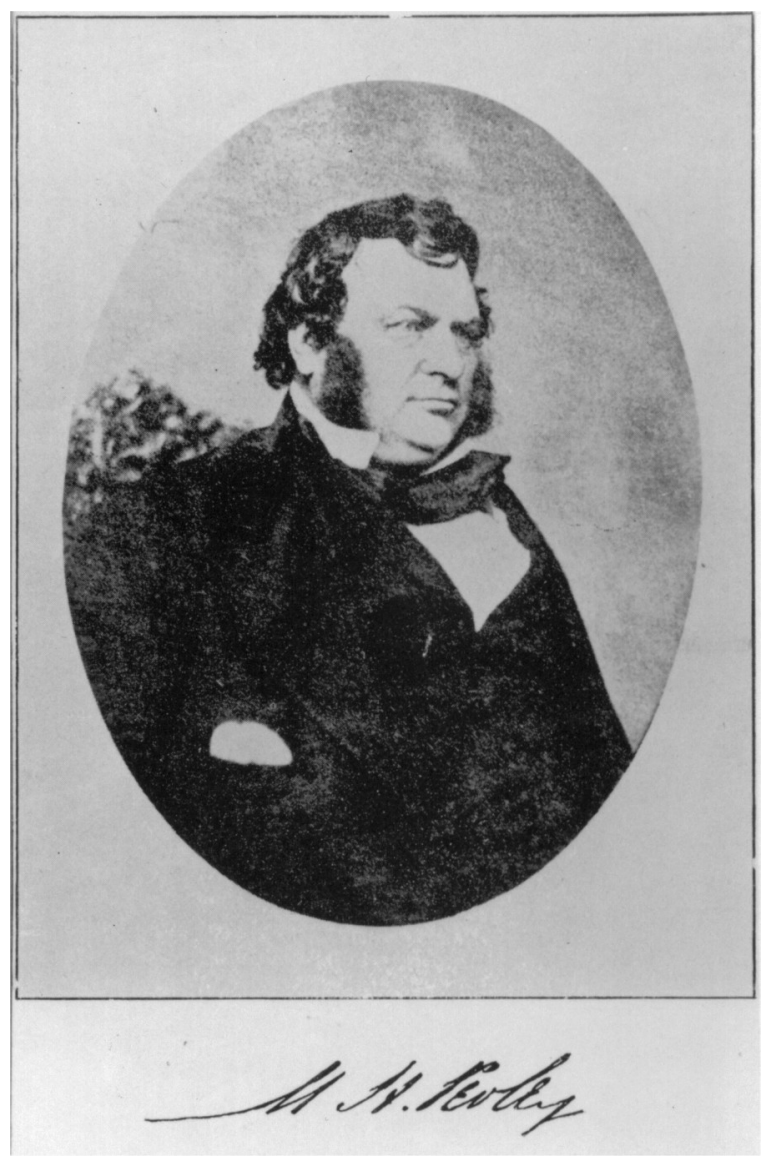

Illustration 1: Moses Perley, not dated. New Brunswick Museum,Saint John, NB, \#00167 PAPG1. (With permission.)
After his father's premature death, Moses and his mother Mary moved to Saint John, New Brunswick, where he received an education in the city's public schools. As a young man he studied law and was called to the bar in 1830 . During the $1830 \mathrm{~s}$ he was involved in lumbering and milling operations in New Brunswick's vast timberlands, not infrequently, it seems, in conjunction with Americans. In the $1840 \mathrm{~s}$ he promoted railway development in New Brunswick and to push railway construction spent time in London in an effort to tap British financial sources. Lord Grey, the colonial secretary, to whom he was introduced said of him at the time that Perley seemed to him to be "a very intelligent man indeed." 2

A keen outdoorsman, too, Perley knew the interior of New Brunswick intimately. From his teenage years he hunted and fished along its rivers and

2 M.H. Perley, Process Book, 1828-1849, NBM; Perley Letters of 16 May, 3, 12, 30 June, and 3 July 1832; 6 Sept. 1833; 31 Jan. and 10 Aug. 1844; 20 Sept. 1845; 13 Sept. 1847; and, 4 and 9 Feb. 1853, Perley Letters 1813-1854; Perley to Wm. Crane, 19 March 1837, New Brunswick Historical Society Papers (hereafter NBHS Papers), MS,NBM; Perley to J. Saunders, 21 Oct. 1846, NBHS Papers; Perley to E.C. Chandler, 13 June 1853, E.C. Chandler Papers, MS, NBM; Thomas Baillie and Moses Perley Letters 1835-1844, 2d35. Records of the Executive Council: Papers Surveyor General's Correspondence, Public Archives of New Brunswick (hereafter PANB), Fredericton, NB; Executive Council Minutes 1834-1842, 4, 3942, 94, PANB; Executive Council Records: Papers, 21, 2188-2211; 22, 2842-2845, PANB; A.G. Doughty, Elgin-Grev Papers 1846-1852. 4 vols. (Ottawa: J.O. Patenaude, 1937), 1:26-27; Henry J. Morgan, "Moses Henry Perley," Bibliotheca Canadensis: or a Manual of Canadian Literature (Ottawa: G.E. Desbarats, 1867), 305-306. 
streams, and he developed a fondness for its natural history as well. ${ }^{3}$ Contact with the natives instilled in him a respect for their ways and culture, and the result was a series of "sketches" he published in the 1830 s and 1840s in which he combined his own knowledge of woodlore with the mythology and traditions of the Indians. ${ }^{4}$ Concern for native welfare led to his appointment as commissioner of Indian affairs. ${ }^{5}$ During the same period he served his colony as chief immigration officer, supervising immigrant arrival and enforcing quarantine regulations, a difficult job at best with thousands of poor immigrants coming from Europe annually. A humane administrator, he assisted in settling new arrivals, and prepared a handbook for immigrants which the province published in $1855 .^{6}$

A busy man already, nonetheless, as Anglo-American relations soured over fishing rights in the $1840 \mathrm{~s}$, Perley directed his energies toward the fisheries. ${ }^{7}$ By decade's end, therefore, with Yankee competition apparently hurting the colonial economy, the government of New Brunswick could ask him - as "the best informed man" on the subject — to report on its fishing trade in the Gulf of St. Lawrence.

"There was no part of the world in which such extensive and valuable Fisheries were to be found as within the Gulf of St. Lawrence," Perley responded in 1849 , but with such unlimited fisheries so close to our shores "it was no less strange than true that they were prosecuted to the greatest extent and profit by citizens of the United States." In particular, he said, "from seven hundred to eight hundred sail of American Fishing Vessels entered the Gulf annually and scattering over the whole of its wide expanse

3 Perley became a founder of the Natural History Society of New Brunswick as well as the Mechanics' Institute of St. John. (See G.E. Fenety, Political Notes and Observations (Fredericton: S.R. Miller, 1867), 70-72, 494-496; and, Perley to Chandler, 14 Nov. 1856, Chandler Papers.)

4 For a listing of his sketches in the Sporting News (London), 1839-41, see Morgan, Bibliotheca Canadensis, 305-306. Also see The Amaranth (Saint John), 1841, 8185, 129-134, 185-189, 215-221, 289-296.

5 Perley Letters, 25 Feb. 1843 and 31 Jan. 1844, Perley Letters 1813-1854; Perley to Saunders, 13 Sept. 1845, 17 Aug. and 27 Oct. 1846, NBHS Papers; Wm. F. Ganong Papers, MS, NBM; Executive Council Records: Papers, 40, 269-273, 308-319; CO 188/106, 180-223, The National Archives (hereafter TNA), Kew, UK.

6 For Perley's career as chief emigration officer, including his correspondence and reports, see Provincial Secretary: Immigration Administration Records 1811-1891, PANB; Executive Council Records: Papers, 31, 113-116, 484-489, 490-495, 496519; 32, 971-990; 100, 2079-2080; Manners-Sutton Letterbook, 7 Oct. 1854, 23 Oct. 1858, 23, 25, PANB; CO 188/127, 585-586, TNA; Perley Letters, 31 Jan. 1844 and 18 Sept. 1847, Perley Letters 1813-1854; Elgin-Grey Papers 1846-1852, $4: 1328$.

7 Perley to Baillie, 29 July 1843, Records of the Executive Council: Surveyor General's Correspondence; Perley Letter, 20 Sept. 1845, Perley Letters 1813-1854. 


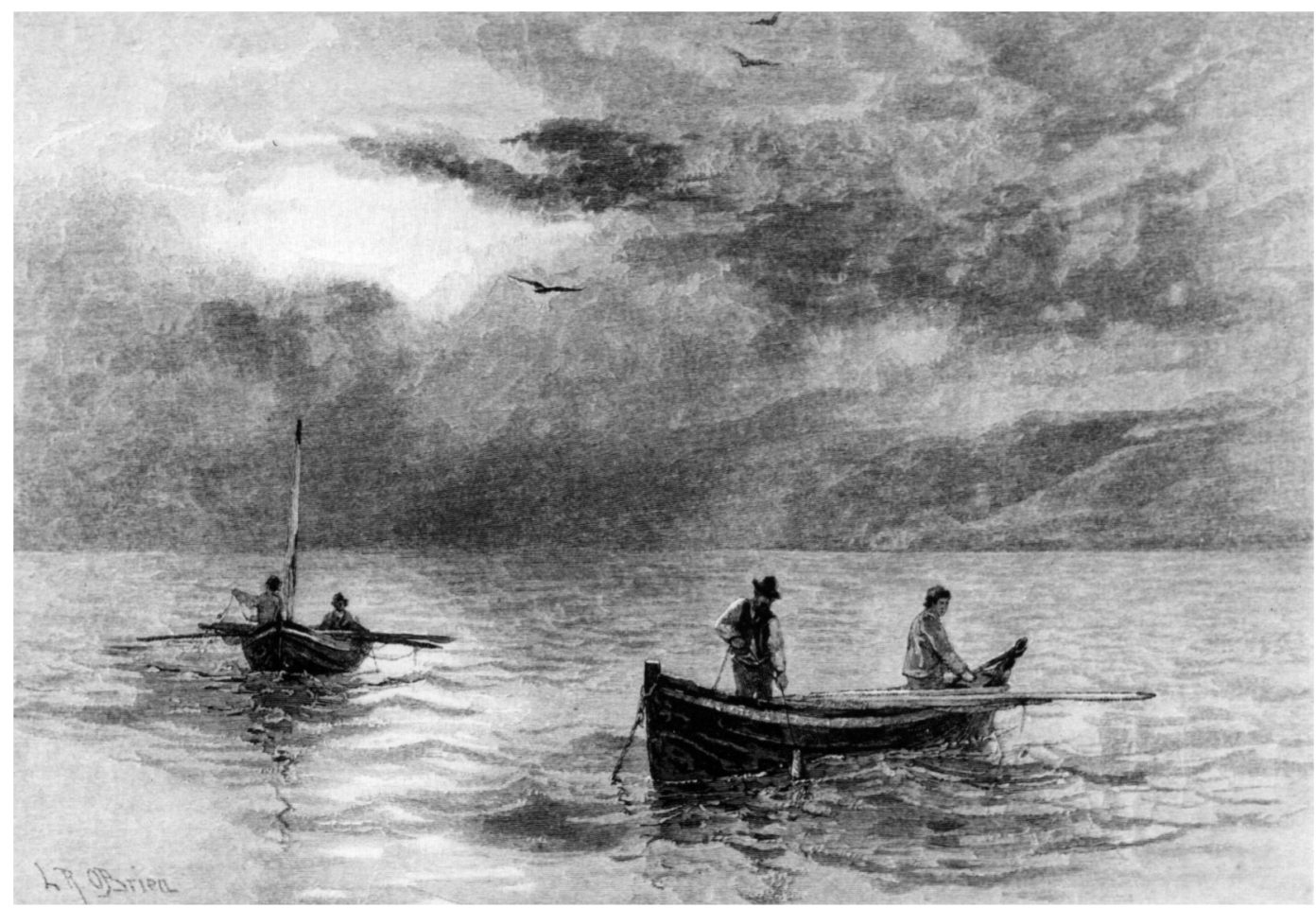

Illustration 2: Cod-Fishing, G.M. Grant, ed., Picturesque Canada: the Country as it was and is, (Toronto, Belden Bros., 1882), 739.

with little heed to the limits to which they were restricted by Treaty, pursued their business unmolested and rarely left without full and valuable fares." 8

And yet it was also true, said Perley, that the people of British America prosecuted their fisheries to a very limited extent. Of the herring fishery he estimated that it barely furnished a sufficient quantity for export, and from an absence of the skill required for its promotion it was made virtually worthless. Herring were taken in the largest quantities in New Brunswick in the spring, said Perley, when they were most unfit to be eaten, "because they were then caught with the greatest ease and least expense." The result was that "thousands of barrels of fish were found [to be] of so little worth they were used to manure the land or left to rot on the beaches." In the fall when herring were in good condition they were taken for a few weeks only "because our fishermen were ignorant of the proper mode of curing them, and did not use drift nets in deep water, which was so successfully practised by the Herring fishers of Scotland." 9

8 M.H. Perley, Report on the Fisheries of the Gulf of St. Lawrence, (Fredericton: J. Simpson, Printer to the Queen's Most Excellent Majesty, 1849), 3.

9 Ibid., 4-7. 
Of the cod fishery, Perley said it was not much followed either by the people of New Brunswick, yet one commonly saw "600 or 700 sail of American schooners" so engaged. The cod fishery of Labrador as well was prosecuted almost wholly by Americans "their vessels being schooners of 70 or 80 tons." The average production of this fishery he estimated at ten quintals of dry fish for every ton of the vessels employed, but he said that "Masters of American schooners were dissatisfied when they failed to catch 12 or 13 quintals per ton." 10

Though mackerel, too, were found "in vast shoals along the whole Coast of New Brunswick," said Perley, the quantity taken by our colonists was so limited as not to furnish a sufficient supply for domestic consumption. Yet the mackerel was a chief object of pursuit by Americans. "In August of last year the waters of the Straits of Northumberland were perfectly alive with Mackerel," he claimed, "and American fishermen took them with such rapidity, and in such quantities, that they were unable to clean and salt the Fish as fast as they were caught."

American mackerel fishers visited the Gulf in vessels of 60 or 80 tons, he continued. "Manned generally by crews of ten men these vessels could catch in a single day ninety packed or 'dressed' barrels of Mackerel, which contained about 12,000 fish." American ships fitted out in Maine and Massachusetts, said Perley, and had two long voyages to make in going to and returning from the fishing grounds. "If it was profitable to them, how much more so could it be made by resident fishermen, who were spared the expense of costly vessels and outfits, high wages, and long voyages." 11

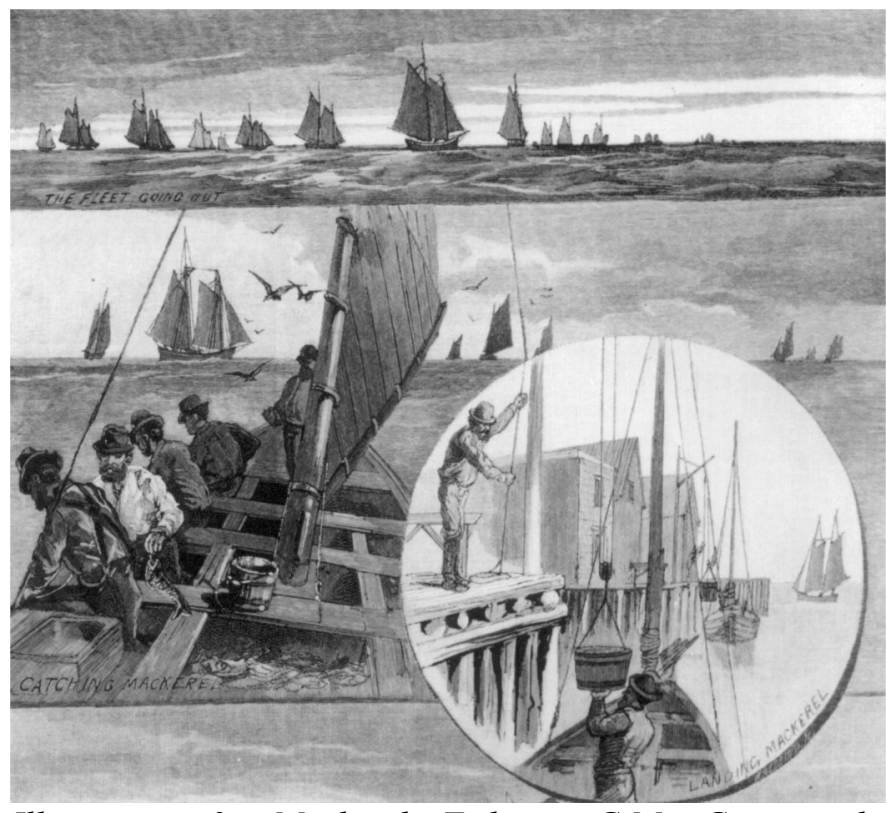

Illustration 3: Mackerel Fishing, G.M. Grant, ed., Picturesque Canada: the Country as it was and is, (Toronto, Belden Bros., 1882), 856.

10 Ibid., 8-13.

11 Ibid., 14-16; Province Secretary Letter Book, 1847-1850, 458, PANB; Perley to Lorenzo Sabine, 19 Oct. and 24 Nov. 1846 and. 31 July 1849, Sabine's Papers, 
Having finished his report and published it in 1849, however, Perley was nonetheless dissatisfied, and the following year he produced another, based this time, he said, on "personal inspection. I left [St. John] on the 12th of August [1849]," and went to Miramichi where "I engaged two canoes and three Indians," and proceeding northward along the Gulf coast of New Brunswick, "visited every Island, River, Creek, Gully, Harbour, and Fishing Station." On the way back "the season being far advanced, and strong easterly gales having set in I could not visit the Coast south of Miramichi by water. I therefore proceeded along the coast by land," returning to Saint John on the 8 th of October 1849. "The whole journey performed [by me] was nine hundred miles, the distance travelled in canoes being nearly five hundred." 12

Again he reported that "the Mackerel Fishery was excellent in the Gulf," though residents did not avail themselves of it; and, "the Herring Fishery was valuable," too, yet from an ignorance of the best mode of curing herring the colonial fishery was unprofitable. This time he added his views on the diplomatic situation.

By the Convention of 1818 between Great Britain and the United States, American citizens could not fish within three miles of the coasts of British America. "Crown officers had given it as their opinion that the prescribed distance was to be measured from the headlands, or extreme points of land, and not from the interior of bays or indents in the coast." Still, Yankee vessels frequented the Straits of Northumberland, the Bay of Miramichi, and the Bay of Chaleur in none of which they had a right to prosecute the fisheries, said Perley. "At present, the Convention of [1818] was openly violated and American citizens enjoyed every privilege they desired save that of landing on our shores to dry and cure their fish. While the Convention existed, [it] should be enforced, or else we lost the advantages of our position without any equivalent."13

The response to his efforts must have gratified Perley, The Morning News (Saint John) called his work "a complete mine of information upon the Fishery resources of this Province," while the New Brunswick Courier (Saint John) said that Perley had furnished "a vast amount of information on the

New Hampshire Historical Society, Concord, NH.

12 M.H. Perley, Report on the Sea and River Fisheries of New Brunswick (Fredericton: J. Simpson, Printer to the Queen's Most Excellent Majesty, 1850), iii-iv, 83, 89-91; Executive Council Records: Papers, 33. 287-290; Executive Council Minutes 1846-1851, 6, 361, 372; Perley to Fulton, 19 July, 8 and 11 August 1849, Provincial Secretary: Immigration Administration Records 18111891: Perley to Partelow, 25 July 1849, ibid; Province Secretary Letter Book 1847$1850,530-531$.

13 Perley, Sea and River Fisheries. 83-84, 102-106. See also Sir Edmund Head to Earl Grey, 4 June 1850 with accompanying Perley memorandum and return correspondence, CO 188/13, 3-11. 
Herring, Cod, and Mackerel Fisheries that till now was scarcely known to exist." The (Miramichi) Gleaner published Perley's first report in full. Commenting on his second report the New Brunswick Courier remarked "there were passages in it which would be found to possess striking interest," and it hoped "the report would be circulated extensively." But the (Miramichi) Gleaner in particular waxed enthusiastic about Perley's second report: "From personal observation we know Mr Perley entered upon his duties with assiduity and was unremitting in his endeavors. We knew too from this learned gentleman's industry and business habits that he would collect a mass of practical information upon which the Government could bring forward measures to develope [sic] the resources of this long neglected branch of industry."

Thus, "we can strongly recommend Mr Perley's work to our patrons" and "assure them it will amply repay a careful perusal. Our gulf swarms with a great variety of fish, and enterprise only is required to prosecute the fishing business successfully. Our inhabitants seem to be sleeping, while the Americans, regardless of the distance, are annually entering our Gulf, and carrying this source of wealth away from our very doors. Can we totally disregard our best interests? It is impossible!" 14

Even more pleasing to Perley, however, was a petition from Saint John fishermen requesting a survey of the Bay of Fundy on New Brunswick's South shore, which the government approved in 1850 and directed him to conduct the following summer. ${ }^{15}$

"I began my survey of the Fisheries of the Bay of Fundy on the 20th of August [I850]," Perley wrote, visiting Grand Manan "in a hooker of 16 tons," then travelled to Campo Bello and the West Isles, surveying the north shore of the Bay "in boats of all sizes. I sailed to the upper part" of Fundy Bay as well, he said, but because "the season was too far advanced, and the weather too stormy I determined" to examine the Nova Scotia shore by land. ${ }^{16}$

"There was a greater variety of Fisheries in the Bay of Fundy than in the Gulf of St. Lawrence," said Perley. For instance, at Grand Manan he described small schooners "fishing for Pollack on the 'rips,' or strong currents, in which the Pollack loved to play, as they found there abundant

14 The [Miramichi] Gleaner. 1 April 1850; also Gleaner, 15, 22, 29 May, 5 June 1849 and 8, 15 April, 27 May 1850; [Saint John] Morning News, 21 March 1849; The New Brunswick Courier (Saint John), 31 March 1849, and 23 March 1850.

15 Executive Council Records: Papers, 33, 144-148, 149-150; Executive Council Minutes 1846-1851, 6, 447-448; Province Secretary Letter Book 1847-1850, 668.

16 M.H. Perley, Report upon the Fisheries of the Bay of Fundy (Fredericton: J. Simpson, Printer to the Queen's Most Excellent Majesty, 1851), 111, 160162. 
Herring for food." To conduct this fishery "vessels were kept under sail with lines attached to seven-foot poles, which projected from the sides of the ship." The bait used was a piece of the pollack itself, "called a 'last'. This being kept in a brisk motion by the sailing of the vessel resembled a living fish darting through the water, and was eagerly chased by the Pollack. Pollack fishers often took twenty fish with a single 'last'," said Perley, "it being a very tough bait."17

Of weiring for herring at Grand Manan, he said there were twentyseven weirs on the island when he was there. Herring were taken in weirs "only on the Spring tides, and at the full and change of the moon," he explained, because "then the fish were swept sufficiently close to shore to be caught." Describing weiring technology, he said the bottom of a weir was constructed of "framed timber of large size sunk in about six feet of water at low tide, and ballasted with huge stones of a ton or more in weight." Above the frame was a "light wicker-work of poles with twigs interlaced, sufficient to retain the timid Herring, but altogether unfit to hold fish of bolder character." Herring "would not leave a weir unless the opening was of large size," said Perley, "while all other fish would dash through any opening sufficient for their passage." 18

He claimed that American vessels frequently fished but a mile off Grand Manan, and that resident fishermen complained they occupied the best fishing grounds, but he also said that young men, from a lack of employment on the island, often enlisted aboard American vessels because they paid good wages. Unfortunately, the people of Grand Manan conducted their fisheries very inefficiently, said Perley, the great difficulty being the low state of education on the island. Islanders "were not sufficiently taught the first rudiments of learning to compete with their American neighbors. If the people of Grand Manan were better taught, and possessed greater knowledge of the world, they would readily see the advantages of their position, and quickly avail themselves of the profits to be derived from it."19

In contrast, the people of Campo Bello "prosecuted the fisheries with great diligence not only in their own vicinity but also by sending their vessels to distant places to procure 'fares'. The fisheries close to Campo Bello were those for Cod, Haddock, and Hake," he said, either "by linefishing on the 'slacks,' or in the coves, and passages where the tide did not set too strong." Herring were also taken in weirs at Campo Bello, and smoked and packed in boxes. Campo Bello vessels "ran down to the Tuskets, the Magdalen Islands, and Newfoundland in the Spring" said Perley, "and, to St. George's Bay in the Winter for Herring. In the Summer they went to

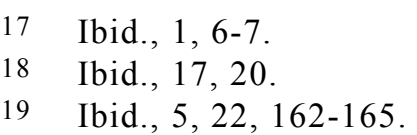




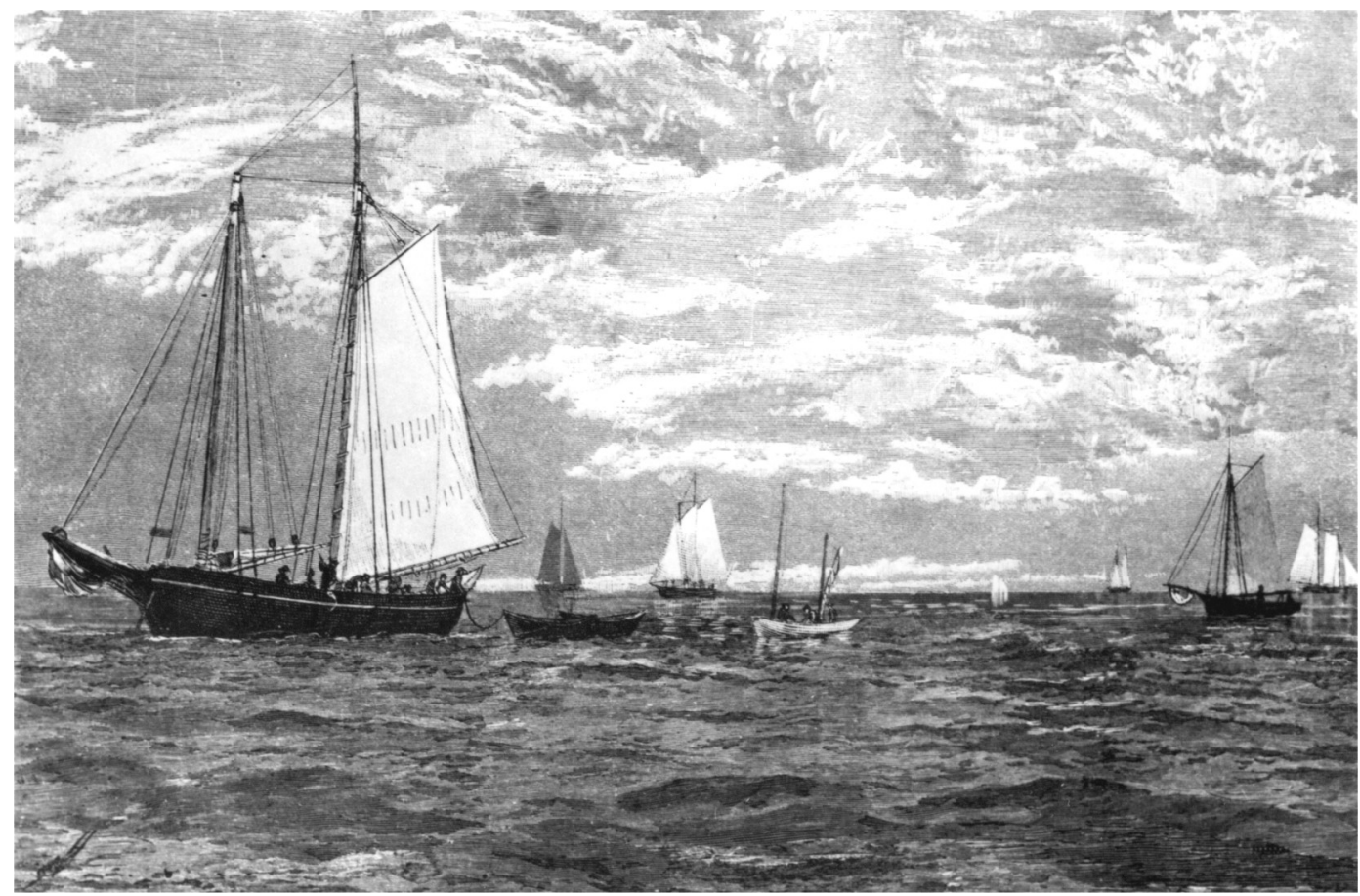

Illustration 4: Fishing schooners off Grand Manan, not dated. Public Archives of New Brunswick, Fredericton, NB.

Grand Manan and Nova Scotia for Herring, Cod, and Mackerel."20

Nearby at the West Isles he described an especially colorful fishery. Here "boats from Eastport and other places in the United States fished equally with the British boats on their own fishing grounds," he said.

"It was a gay scene on a fine day to mingle with some two or three hundred boats fishing the Big Eddy near Indian Island, lying so close together as to leave little more than space between them to pull up fish. I joined this throng more than once when Pollack were taken of large size and in great abundance." Fishing began on "the slacks," the boats being then at anchor. When the tide started to run, the anchors were lifted, and the boats swung about to begin fishing " on the drift'. This continued until the tide began to set too strong, when the boats proceeded to the coves and eddies near Campo Bello to fish out the rest of the tide.'

There were generally three men to a boat, he continued, and "all was life, bustle, and animation." Lines were scarcely down when a fisherman drew up a fish. As the fish were drawn into the boats, "jokes and gibes were freely bandied; any lively story, or piece of stinging wit passed quickly from 
boat to boat, and laughter, cheers and invariable good temper prevailed among all, whether British or Americans. When the British boats went over to Eastport to dispose of their catch, no questions were asked as to the character of the boat...If the American boats enjoyed the privilege of fishing on the best grounds within the limits of New Brunswick, those of the West Isles could sell their fish at Eastport without payment of duty or charges."

"The good feeling which sprang from this state of things caused the fishery business to go on smoothly and quietly along the frontier," said Perley, "where under other circumstances there would almost certainly have been constant quarrels and collisions." 21

Indeed, despite the "good feeling" at the West Isles, Perley was not optimistic about British fisheries in the Bay of Fundy. He concluded: "It was clear the careless manner of curing fish by British Americans, whether from neglect or want of skill was such as to prevent those fish obtaining good prices and prohibited their being sold in foreign markets," and once more he warned that "the intrusion of American fishing vessels upon the fishing grounds of the Bay of Fundy was loudly complained of by British fishermen." Measures had to be taken "for keeping those vessels without the limits established by the Convention of 1818 , either by requesting the services of the Royal Navy, or else by employing Fishery Cutters at the joint expense of New Brunswick and Nova Scotia.",22

Again Perley's labors gained him public acclaim. The New Brunswick Courier termed his report "spirited and graphic," and added, "this most valuable and useful Report possessed great interest and a vast amount of information which should be generally-disseminated. " The British Colonist (Halifax) said that "Perley's report is excellent, and is as valuable to Nova Scotia as it is to New Brunswick for it treats the subject of the fisheries as a whole. As the author has long since distinguished himself for energy and ability, an able performance was naturally enough expected, but in the present work Mr Perley has exceeded himself, and his report will be read with much interest and advantage." Farther away the Colonial Review (London) upheld Perley's views on the fisheries, while the Anglo-American Magazine (Toronto) concluded that Perley's work "is replete with curious facts and well digested details. To the statesman and naturalist alike [it] equally commends itself." From the governments of Canada and Nova Scotia came official requests for "Twenty-five Pounds worth of Mr Perley's Fishing

Ibid., 28-29.

22 Ibid., 114, 115; Perley to Mary Perley, 24 Sept. 1850, Perley Letters 1813-1854; Executive Council Records: Papers, 33,. 151-154. Accompanying Perley's Bay of Fundy report was a "Catalogue [in part] of the Fishes of New Brunswick and Nova Scotia." A second, combined edition of Perley's reports appeared in 1852. 
Reports," that is, 500 copies each. ${ }^{23}$

In the early 1850 s Perley finished his surveys, and was active in promoting protectionist policies for the fisheries. ${ }^{24}$ At the same time, however, he realized the fisheries were crucial in solving new problems facing British America. After Britain adopted free trade at mid-century in place of colonial preference, Perley, like many colonists, favored closer commercial ties with the United States. If colonial fisheries were opened to Americans with proper controls for the colonists, he reasoned, then colonial goods in return could be dealt for items of American manufacture.

So, Perley became part of an Anglo-American initiative in the fifties that sought to secure a reciprocal trading agreement between British North America and her Yankee neighbor to the south. ${ }^{25}$

Committed already to reciprocity in the 1850s was Israel Andrews, a Yankee that Perley knew well. Born in Eastport, Maine in 1813, Andrews became United States consul at Saint John in 1843, perhaps when Perley first met him. A strict continentalist who favored trade inside North America uninterrupted by borders, Andrews was appointed special agent by Washington in 1849 to gather commercial intelligence on British America. The result was two substantial statistical studies which sustained Andrews' geo-economic views on the viability of reciprocity. As a British-American and one who was savvy in the world of politics, Perley was a valuable addition to the ranks of Andrews and company to aid in lobbying officials imperial, provincial, and American, and to influence public opinion. Success for the international collaboration came with the Reciprocity Treaty of 1854 which opened the fisheries of British America to Yankees, and produced a free list of articles that might be traded between the provinces and the United States. Appointed British commissioner, who along with an American

23 The New Brunswick Courier. 26 April 1851; The British Colonist (Halifax), 1 May 1851; "The American Fisheries," The Colonial and Asiatic Review 1 (1852): 234-243; The Anglo-American Magazine 1 (1852): 359; Executive Council Records: Papers, 33, 187-188, 189-191.

24 Perley Letter, 18 June 1853, Provincial Secretary: Immigration Administration Records 1811-1891; Executive Council Minutes, 1851-1857, 7, 194-196, PANB; Provincial Secretary Letterbook 1850-1854, 465, 524,PANB; Perley to Chandler, 22 Jan. 1851 \& 13 July 1853, Chandler Papers; Perley to Blackwood, 10 May 1851, Perley Letters 1813-1854; Executive Council Records: Papers, 33, 156-157, 158-161; Executive Council Minutes, 1846-1851, 6, 549; Acts of the General Assembly of Her Majesty's Province of New Brunswick Passed in the Year 1851 (Fredericton: J. Simpson, Printer to the Queen's Most Excellent Majesty, 1851), 28, 48-50.

25 Perley to Chandler, 22 Jan, and 15 Oct. 1851; 26 Feb. and 10 Nov. 1852; 13 June and 8, 13 July 1853, Chandler Papers; Perley to Mary Perley, 13 Mar. 1852, Perley Letters 1813-1854. 
counterpart was to administer the fishery portions of the reciprocity treaty, was Moses Perley. ${ }^{26}$

As Her Majesty's North American Fishery Commissioner in the years that followed Perley employed a variety of vessels to carry out his diplomatic duties. Initially, he had "the Cutter "Halifax"," he said, and later "a fine Brigantine of 100 tons"; then he mentioned "a first-class vessel" and a "Steam Sloop-of-war." Finally, he cruised aboard HMS Desperate. ${ }^{27}$ And, it was cruising the waters of British America in the 1850s that Perley grew wary of American interest in Newfoundland. "You are doubtless aware of the extreme anxiety of the Americans to possess Newfoundland," he wrote the Foreign Office in 1857. They began their operations with The Electric Telegraph Co., obtaining "from the Government of Newfoundland a monopoly of telegraphic communication in that Island for fifty years, with a grant of about $£ 3000$ in money and 30,000 acres of land on completing the line of telegraph from St. John's by the Southern Coast to Cape Ray, \& thence by submarine cable to Cape Breton."

Thus, they obtained a footing in Newfoundland and were selecting the

26 Wm. R. Manning, ed., Diplomatic Correspondence of the United States Canadian relations, 1784-1860, 4 vols. (Washington: Carnegie Endowment for International Peace, 1945), 3:202, n. 1, 976-977, 1027, 1143-1148, 1159-1162; 4: 13-14, 285286, 304-307, 626-627, 632-633; Report of the secretary of the Treasury in answer to a resolution of the Senate calling for information in relation to the trade and commerce of the British American colonies with the United States..., 31st Cong., 2nd sess., Senate Executive Document (Sen. Ex. Doc), No. 23 (Washington, 1851); Communication from the secretary of the Treasury, transmitting, in compliance with the resolution of the Senate of March 8, 1851: the report of Israel D. Andrews on the trade and commerce of the British North American colonies ..., 32nd Cong., 1st sess., Sen. Ex. Doc, No. 112 (Washington, 1853); Irene W.D. Hecht, "Israel Andrews and the Reciprocity Treaty of 1854: A Reappraisal," Canadian Historical Review 44 (1963): 313-329; Wm. D. Overman, "I.D. Andrews and Reciprocity in 1854: An Episode in Dollar Diplomacy," Canadian Historical Review 15 (1934): 256, 262; Donald C. Masters, The Reciprocity Treaty of 1854 (London: Longmans, Green and Co., 1936); C.C. Tansill, The Canadian Reciprocity Treaty of 1854 (Baltimore: The Johns Hopkins Press, 1922); Perley to Keefer, 4 May 1854 and 5 May 1852 in Thomas C. Keefer, A Sketch of the Rise and Progress of the Reciprocity Treaty (Toronto: Lovell and Gibson, 1863),5-7, 13, 15-16, 19, 21, 27; Lester B. Shippee, Canadian-American Relations. 1849-1874 (New Haven: Yale University Press, 1939), chaps. 1-4; Perley to Young, 29 Nov. 1854, Perley Letters 1813-1854; Executive Council Records: Papers, 33, 208-209, 211-214; Provincial Secretary Letterbook 1854-1857, 76, PANB; Perley to Chandler, 9, 16, 19 May 1855, Chandler Papers.

27 Perley to Chandler, 19 May, 7 Aug., 27 Oct. 1855; 27 Apr., 30 June 1856, Chandler Papers; Perley to Gordon, 22 May 1862, Provincial Secretary: Immigration Administration Records 1811-1891; Manning, ed., Diplomatic Correspondence 4: 732 . 
land in the most favorable positions for mining and other purposes. "But I am now informed they propose abandoning the overland line of 400 miles in Newfoundland and landing the Atlantic cable in Trinity Bay, taking a line across the narrowest part of the Island and thence by another cable direct to Nova Scotia, touching at St. Pierre and Miquelon, and placing those Islands in telegraphic communication with Paris."

"The United States Commissioner will be most anxious to extend the privileges conceded by the Reciprocity Treaty in Newfoundland to their utmost limits," Perley concluded, "\& if possible involve the Governments of England \& France $^{28}$ in a dispute. Hence the necessity of great care \& caution now." 29

More pressing for Perley than American intrigues in Newfoundland, however, were problems arising from the reciprocity treaty itself. Its provisions applied to the sea fisheries only of British America and not to the area's rivers from which Yankee fishermen were excluded. So, the precise geographical points at which provincial rivers ended and the sea began were tasks left to Perley and his American counterpart to determine. Not surprisingly, disagreements arose, for as Perley wrote London: "The U.S. Commissioner appears desirous of placing the mouth of each river as far up as it is possible, in order to give American vessels the right to enter the harbours at their mouths without question or hindrance under pretense of fishing." 30 The treaty looked to resolve disagreements by having the commissioners appoint an umpire to arbitrate, but the process proved slow and even contentious as the quantity of documents in England and Washington shows. Happily, it seems, conflicts were ultimately settled to the mutual satisfaction of Britain and the United States. ${ }^{31}$

In the summer of 1862 tragedy accompanied Perley on his tour of inspection. As Commander Thrupp of HMS Desperate reported, "when leaving Newfoundland Mr Perley complained of being unwell and seldom left his cabin. We thought it advisable, therefore, to leave at once for home." Later, "a favorable change took place, \& Mr Perley begged me to turn back as he felt strong enough to do his duty." From that time on he rallied, but "suddenly he became worse, and then insensible in which state he remained

28 France enjoyed fishing rights in Newfoundland from earlier treaties.

29 Perley to Hammond, 10 March 1857, F0 115/174, 72-73, TNA; Perley to Chandler, 16 June 1856, Chandler Papers.

30 Perley to Clarendon, 6 October 1855, FO 115/155. 379-387.

31 F0 115/222, 25-31; FO 115/223, 259-328; Manning, ed., Diplomatic Correspondence, 4:146-147, 208-214, 230-235, 700, 836-839; Shippee, CanadianAmerican Relations. 1849-1874, 89-95. For the printed text of the Fishery Commission's work see John Bassett Moore, History and Digest of the International Arbitrations to Which the United States Has Been a Party (Washington: Government Printing Office, 1898) 1: 426-491. 
until he breathed his last on the 17th of August."32 Perley was buried with naval honors at Forteau Bay on the desolate coast of Labrador.

Moses Perley is an important figure in the history of the fisheries. Asked by government to report on the fisheries in the seas around New Brunswick, he produced several impressive studies notable for their statistical data, of course, but studies which are remarkable too for the literary style with which Perley depicted the nineteenth-century fisheries, British and American, and maritime scenes in particular with color and clarity. Determined to protect colonial fisheries, Perley accepted American entry into provincial inshore waters only because he thought it would improve trade relations with the United States for all of British America. And, once he became British commissioner under the reciprocity treaty, he read its provisions strictly in order to protect the interests of colonial fishermen. Without question,

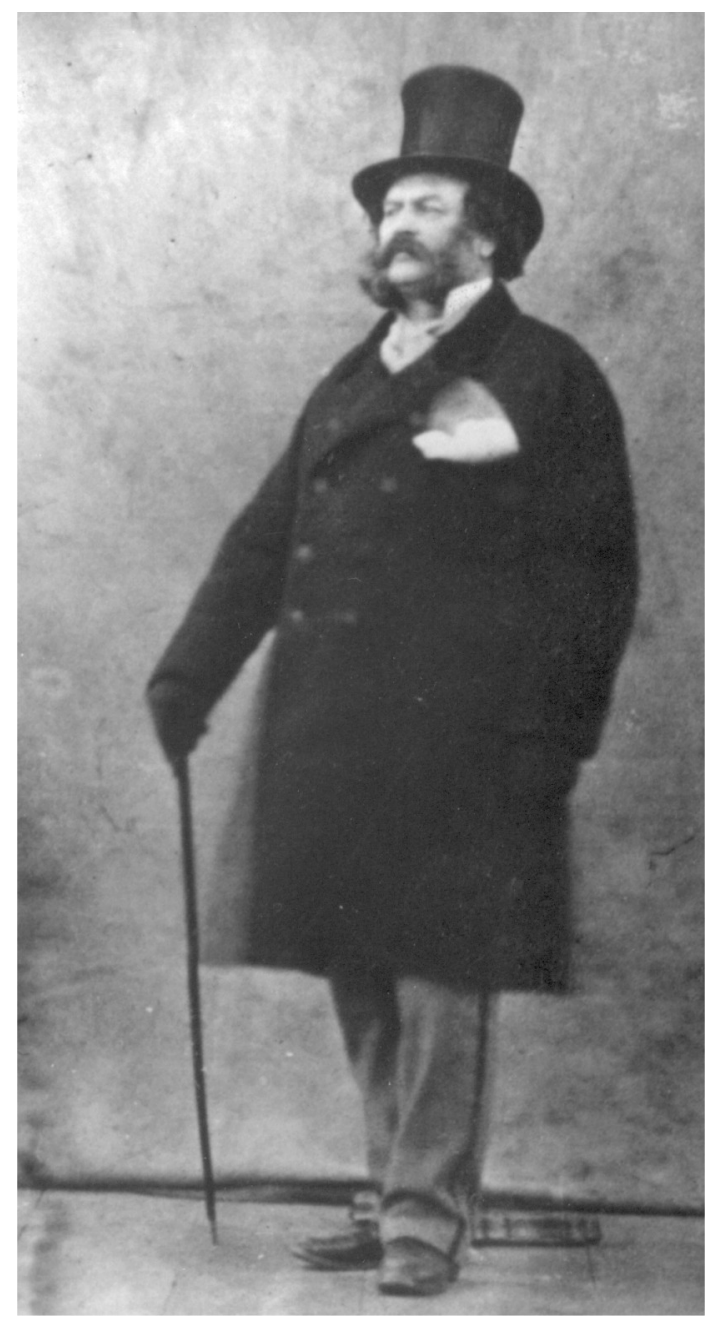

Illustration 5: Moses H. Perley, Her Majesty's North American Fishery Commissioner, ca. 1860. NBM (with permission.) Perley's story is integral to the history of the nineteenth-century North Atlantic fisheries, and it is a story that needs to be told.

32 Commander Thrupp to Admiral Milne, 22 August 1862, CO 188/137, 387-389. 